\title{
Megkésett köszönet Darrick Danta professzornak
}

\author{
Belated thanks to professor Darrick Danta
}

\author{
TIMÁR JUDIT
}

A Tér és Társadalom olvasói ismét búcsúzni kénytelenek egy kollégától, - többek számára - jó baráttól. Darrick Danta, a California State University, Northridge (CSUN) társdékánja, a Földrajz Tanszék professzora, folyóiratunk szerkesztőbizottságának tagja 58. születésnapján hegyi túrára indult, s többé nem tért vissza.

A tájat annak természeti-társadalmi alkotóelemeivel megérteni vágyó geográfust tanulmányai nagy része $s$ teljes egyetemi tanári munkássága a CSUN-hoz kötötte. Kutatói érdeklődése azonban - mint ő maga írta - inkább egy kanyargós folyamot, mintsem egy egyenes vonalat követett. Magyarországi kapcsolatait még e kanyargós pálya elején kezdte építeni, amikor az urbanizáció elméleti-módszertani kérdései foglalkoztatták. Doktori disszertációját a magyar városrendszer hosszú távú agglomerációs/deglomerációs trendjeinek jellemzőiről írta, s erről tartott előadást is 30 évesen, első magyarországi konferenciaszereplésén.

Mostanában, amikor végre nálunk is kibontakozóban van a tértudományok történetének, tudományszociológiai kérdéseinek tanulmányozása, gyakran töprengek arról, hány tudós kollégát „hagytunk elmenni” úgy, hogy nem kérdeztük meg őket diszciplínáink nagy átalakulásainak általuk megélt valóságáról. Darrick Danta, ha nem is érhette még el a „nagy öreg” címet, sokat mondhatott volna nekünk önmagunkról. Azokban az izgalmas '80-as években tűnt fel nálunk, amikor a hazai fiatal generáció is egyre több esélyt kapott arra, hogy „helyébe jöjjenek" a nyugati geográfia, a regionális tudomány ismert (vagy később ismertté vált) képviselői. Egyre-másra rendezték Magyarországon a hollandokkal, franciákkal, britekkel kialakított intézményes kapcsolatokat erősítő szakmai találkozókat. Közéjük tartozott az amerikai-magyar, a regionális fejlődésről és fejlesztésről szóló, Pécsett és Budapesten 1985-ben tartott konferencia is. Ekkor Darrick Dantával nemcsak mint előadóval ismerkedhettünk meg, hanem ő lett a Regionális Kutatások Központja új, Regional Research Reports címü angol nyelvü könyvsorozata 2. kötetének (Regional development processes and policies) egyik szerkesztője is. Nekem ebben a munkában sikerült vele először együtt dolgoznom, de többen kötöttünk vele ekkortájt barátságot. Később többünket

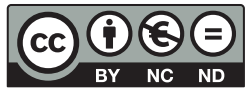


fogadott saját tanszékén, ismertetett meg bennünket ottani kutatási eredményeikkel. Közben maga is egyre sokoldalúbb érdeklődéssel fordult egész régiónk felé. Visszajáró vendégünk lett, a békéscsabai csoportnál nem egyszer töltött rövidebb-hosszabb időt. A magyar városhálózat átalakulásáról nemcsak nyugati folyóiratokban jelentetett meg írásokat, de az Alföldi Tanulmányokban is örömmel publikált.

Az ő hozzáállása nagyon távol állt a sokat kritizált angol-amerikai hegemóniát fenntartó attitűdtől. Őszinte érdeklődéssel járta be velünk a békési tanyákat, szegény falvakat, a Körösök vidékét is. Már akkor meg akarta érteni a kelet-európai tájat/teret formáló szocialista társadalmi viszonyokat, amikor még nem lehetett ebből „Nyugaton” gyors karriert építeni, s akkor is megmaradt régiónk, idővel főleg Délkelet-Európa, a Balkán tanulmányozásánál, amikor már kevésbé számítottunk kuriózumnak. Mint a rá emlékező internetes bejegyzések is tanúsítják: nagyszerü tanár lehetett. Olyan geográfus, akire innen nézve is nyugodtan rábízhattuk a magyarországi térről és társadalomról szóló ismeretek oktatását.

Elvétve találni az amerikai (vagy más nyugati) geográfusok között olyanokat, akik a nyelvünket is megtanulták vagy legalább megpróbálták elsajátítani akkor is, ha nem kizárólagos kutatási témának választották Magyarországot. Darrick Danta közéjük tartozott - kedves humora leveleit is áthatotta, melyekben gyakran élcelődött saját nyelvbotlásain. Mindvégig figyelemmel kísérte a térfolyamatokról, területi politikáról a mi mühelyeinkből kikerült angol nyelvű publikációkat, s 2005-ben, az Enyedi György születésnapjára készülő kötetben (Hungarian spaces and places: patterns of transition) egyetlen kérő szóra elvállalta a nyelvi lektor nehéz szerepét. Erre a munkára áldozta a nyara egy jelentős részét, csak az elmaradhatatlan hegymászó hétvégékre kérve egyszer-egyszer „kimenőt”. Örömmel tett eleget az újjászerveződő TéT szerkesztőbizottságába szóló meghívásunknak is, és biztos vagyok abban, hogy nem csupán cikkeink angol absztraktjait futotta át.

Régóta azt reméltem, hogy talán hamarosan megint váratlanul betoppan, $\mathrm{s}$ végre méltó módon tudjuk neki megköszönni a sok segítséget, érdeklődést, a magyar geográfiához füződő viszonyát. Szívből sajnálom, hogy ezt már nem tehetjük meg. 